\title{
A case of herpes zoster masquerading as stereotactic body radiation therapy associated chest wall pain in a patient treated for primary non-small cell lung cancer
}

\author{
Ram Y Narayan, Shaio Y Woo, Neal E Dunlap \\ Department of Radiation Oncology, University of Louisville, Louisville, KY, USA \\ Correspondence: Neal E Dunlap. Address: Department of Radiation Oncology, University of Louisville, Louisville, KY, \\ USA. E-mail: nedunl01@louisville.edu \\ Received: January 7, 2013 \\ Accepted: January 29, 2013 \\ Online Published: February 1, 2013 \\ DOI : $10.5430 /$ jst.v3n2p19 \\ URL: http://dx.doi.org/10.5430/jst.v3n2p19
}

\section{Abstract}

Introduction: Lung cancer is the leading cause of cancer-related death in the United States. In patients with Stage I non-small cell lung cancer (NSCLC) deemed medically inoperable due to comorbities, stereotactic body radiation therapy (SBRT) is a reasonable treatment option. We are reporting a case of a medically inoperable patient with Stage I NSCLC who received SBRT to the lung. The patient presented with herpes zoster masquerading as radiation-related chest wall pain.

Presentation: The patient was a 76-year-old Caucasian female with a 40-pack year history of tobacco use who presented with a solitary pulmonary nodule on chest x-ray during a chronic obstructive pulmonary disease (COPD) exacerbation. Workup revealed squamous cell carcinoma, and the patient was determined to be medically inoperable due to poor lung function secondary to COPD. Nine months after completion of SBRT, the patient presented with chest wall pain that evolved into herpes zoster along the T4 dermatome.

Conclusion: Because herpes zoster most commonly presents as a pain episode before rash eruption, it can be easily mistaken for chest wall pain alone. Herpes zoster can be treated effectively with anti-viral medications and anti-inflammatory agents. Thus, it is important to keep zoster in mind for patients who receive SBRT to the lung and follow-up with chest wall pain.

\section{Key words}

Stereotactic body radiation therapy, Chest wall pain, Herpes zoster

\section{I ntroduction}

Lung cancer is the most common cause of cancer related death in both men and women in the United States. It causes more cancer related deaths than the three next most common types of cancer — colon, breast, and prostate — combined ${ }^{[1]}$. Non-Small Cell Lung Cancer (NSCLC) accounts for approximately $80 \%$ of lung cancer nationwide. Currently, in patients with stage I disease who do not have any contraindications to surgery, standard treatment involves anatomic lobectomy 
with an expected five-year overall survival as high as $60-70 \%{ }^{[4,5]}$. In patients with contraindications to surgery [typically due to refusal of surgery or low pulmonary function due to long standing chronic obstructive pulmonary disease (COPD)], stereotactic body radiation therapy (SBRT) has become a common alternative treatment ${ }^{[6]}$.

SBRT delivers hypofractionated high-dose radiation to a very specific target volume ${ }^{[6]}$. In early stage, inoperable NSCLC, local control rates have been reported up to $98 \%{ }^{[6,7]}$. Additionally, SBRT has been shown to cause low rates of treatment-related toxicity ${ }^{[8-14]}$. In the past, medically inoperable patients were often treated with primary conventional external radiation therapy. In medically inoperable patients with nonmetastatic clinical stage I NSCLC, reported 5-year survival rates with conventional external radiation therapy were as low as 6-21\% ${ }^{[15-17]}$. In medically inoperable patients with Stage I NSCLC treated with SBRT, however, 3-year overall survival was reported as $55.8 \%{ }^{[20]}$.

SBRT treats a more focused target area than conventional external radiation therapy. Thus, one of the benefits of SBRT is less toxicity to normal tissue due to the reduction of normal tissue receiving toxic radiation doses. Still, SBRT is not without its share of toxicities. In a paper by Hoyer and colleagues, patients treated with SBRT for limited stage NSCLC were followed in order to determine associated toxicities. The most frequent side effects in this patient population were chest wall pain, esophagitis, pneumothorax, dyspnea, mild nausea, and erythema ${ }^{[21]}$. Other studies have also reported chest wall pain along with an increased frequency of rib fractures ${ }^{[22-24]}$. Acute skin toxicity is also reported, which correlates with proximity of the lesion to the chest wall and subsequent total skin dose received in the treatment plan ${ }^{[26]}$.

Due to the relatively recent implementation of SBRT for medically inoperable early stage NSCLC patients, there is potential for other, previously unreported toxicites that are associated with this treatment. We are presenting a case of herpes zoster in the setting of SBRT in a patient with medically inoperable squamous cell carcinoma of the lung.

\section{Case presentation}

\subsection{Presentation}

A 76-year-old female with a 40-pack year history of tobacco use was found to have a solitary pulmonary nodule on a chest x-ray during a COPD exacerbation. A CT scan of the chest demonstrated a $4.0 \times 3.2 \mathrm{~cm}$ left upper lobe lung mass near the 4th and 5th intercostal spaces. A subsequent positron emission tomography (PET)-CT was obtained which showed hypermetabolic activity within the mass with a maximum standard unit value (SUV) 12.2. There was no evidence of metastatic disease. A CT-guided percutaneous biopsy showed squamous cell carcinoma (SCC). The patient was evaluated in a multidisciplinary setting and determined not to be a surgical candidate due to a forced expiratory velocity in 1 second (FEV1) $<30 \%$ and the necessity for continuous oxygen supplementation of 2-3 liters. The decision was made to treat the patient with SBRT.

\subsection{Treatment}

The patient underwent four-dimensional CT (4DCT) to determine tumor respiratory motion for treatment planning. An internal target volume (ITV) of $14 \mathrm{cc}$ was delineated and an additional $5 \mathrm{~mm}$ was placed around the volume circumferentially to create a planning target volume (PTV). A total dose of 5,400cGy was delivered in 3 fractions over 7 days using volumetric modulated arc therapy (VMAT) technique. Care was taken to minimize dose to the chest wall using a dose constraint of $30 \mathrm{cc}$ of the chest wall receiving $\leq 3,000 \mathrm{cGy}$ (See Figure 1). The dose volume histogram (DVH) for the chest wall was acceptable with $14 \mathrm{cc}$ receiving $3,000 \mathrm{cGy}$. Daily cone beam CT (CBCT) was used to align the patient on a daily basis. 
Figure 1. Treatment Plan and DVH (top right) for the patient who developed shingles after receiving SBRT to the lung

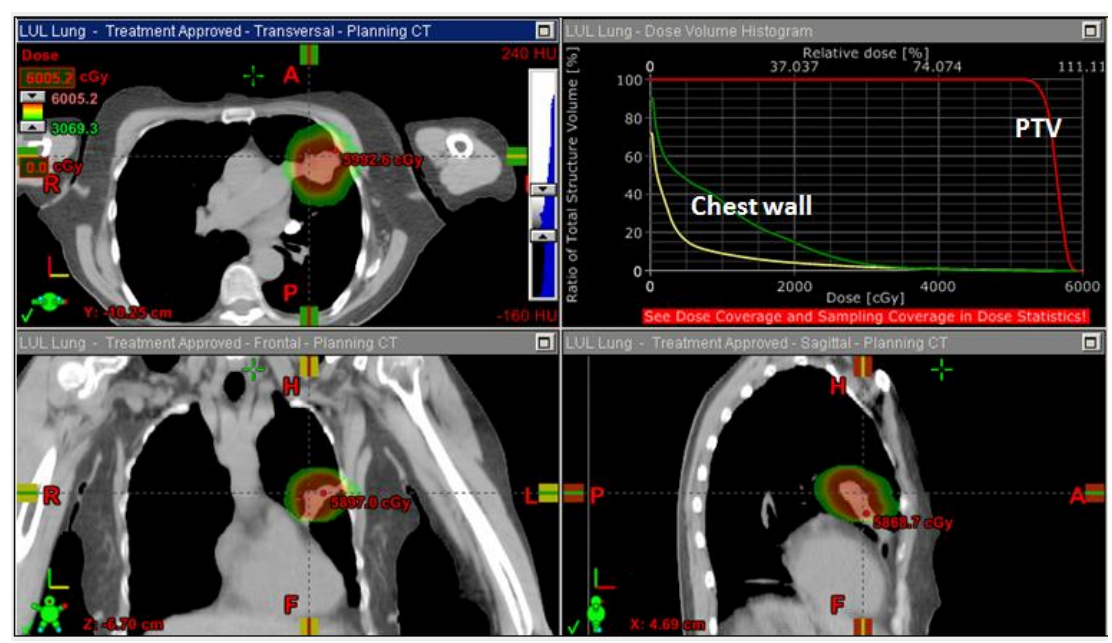

\subsection{Toxicity}

Approximately 9 months after the completion of SBRT treatment, the patient presented to her medical oncologist with the complaint of pain in the left scapular region. The patient was started on narcotic analgesics with some improvement. Approximately 10 days after the initial pain, the patient developed a vesicular rash along the left T3-T4 dermatome (see Figure 2). The rash was clinically described as herpes zoster. The patient was started on acyclovir and anti-inflammatory agents. Within 30 days the patient's symptoms and rash improved. Twelve months after treatment, the pain was minimal and controlled with over the counter analgesics.

Figure 2. The patient is shown with the classical T3-T4 dermatomal vesicular rash often seen with shingles. The location of the rash corresponds to the adjacent dermatome of the treated lung tumor.

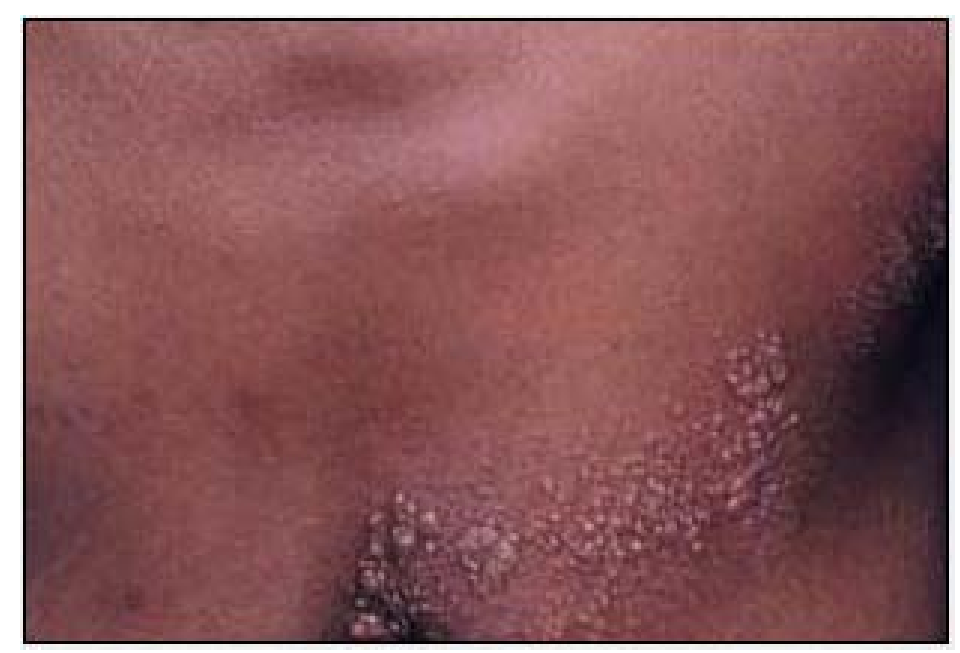

\section{Discussion}

SBRT is a treatment option for medically inoperable patients with early stage NSCLC. Recent prospective data has shown primary tumor control rates of $97.6 \%$, local control rates of $90.6 \%$ and 3 year overall survival of $55.8 \%$, with a modest toxicity profile ${ }^{[20]}$. The most common toxicities associated with SBRT in this patient population include skin toxicity and chest wall pain. Chest wall pain occurs in approximately $30 \%$ of patients treated with SBRT at a median time of 7 months ${ }^{[22]}$. We have observed a case of herpes zoster in a patient with NSCLC treated with SBRT that was initially 
believed to be SBRT-related chest wall pain. In an extensive search of the literature on PubMed, we have not found any similar case reports.

Published studies have highlighted the increased risk of herpes zoster infection in cancer patients ${ }^{[27]}$. One study published by Dunst and colleagues examined the risk of herpes zoster infection in breast cancer patients receiving adjuvant conventional radiation therapy. They concluded that those patients were at a 3- to 5-fold higher risk of developing the infection when compared to the general population ${ }^{[28]}$. Additional reports from the United Kingdom show an increased risk of herpes zoster within the local radiation field treatment with combined modality therapy for small cell carcinoma of the lung ${ }^{[29]}$. Until now, however, we do not believe there have any reports of shingles following SBRT in a patient with NSCLC.

The relationship of local radiation therapy and herpes zoster has not yet established. Determining a cause and effect relationship is complicated by the high incidence of herpes zoster in an older population within the thorax. A normal age-related decrease in cell-mediated immunity increases the risk for reactivation. Cellular stress response and immune response, specifically heat shock response, has been implicated in the mechanism of herpes simplex virus (HSV) reactivation ${ }^{[30]}$. Recent studies have demonstrated that radiation can play a pivotal role in stimulating the immune response by causing an elevation in circulating serum heat shock proteins ${ }^{[31]}$. The relationship between the heat shock response and radiation may be one explanation for HSV reactivation.

Herpes zoster infection is a seemingly uncommon yet may occur in conjunction with SBRT treatment for lung cancer. Practitioners should keep this presentation in mind when following up with patients treated with SBRT, especially with chest wall pain in a dermatomal distribution. The classic presentation of shingles involves pain followed by a vesicular rash in a dermatomal distribution. Because chest wall pain is a more common side effect associated with SBRT, a patient presenting during the initial pain period may be initially treated with narcotic analgesics alone, as was the case with our patient. A closer follow-up is indicated, however, because of the potential for underlying shingles and subsequent rash eruption. Once identified, shingles can be easily treated with acyclovir and anti-inflammatory agents. Therefore it is important to consider shingles on the differential diagnosis for medically inoperable early stage NSCLC patients presenting with pain after receiving SBRT to the lung.

\section{Conflict of interests}

The authors declare that they have no conflict of interests.

\section{References}

[1] American Lung Association [Internet]. Available from: http://www.lung.org/lung-disease/lung-cancer/resources/facts-figures/lung-cancer-fact-sheet.html (21 Dec 2012, date last accessed).

[2] Cancer Care [Internet]. Available from: http://www.lungcancer.org/reading/types.php (21 Dec 2012, date last accessed).

[3] National Cancer Institute [Internet]. Available from: http://www.cancer.gov/cancertopics/pdq/treatment/non-small-cell-lung/Patient/page4 (21 Dec 2012, date last accessed).

[4] Ginsberg RJ and Rubinstein LV. Randomized trial of lobectomy versus limited resection for T1N0 non-small cell lung cancer. Ann Thoracic Oncol. 1995; 60: 615-623. http://dx.doi.org/10.1016/0003-4975(95)00537-U

[5] Swanson SJ, Herndon JE, D'Amico TA, Demmy TL, et al. Video-assisted thoracic surgery lobectomy: report of CALGB 39802-A prospective, multi-institutional feasibility study. JCO. 2007; 25: 4993-4997. PMid:17971599 http://dx.doi.org/10.1200/JCO.2007.12.6649

[6] Potters L, Steinberg M, Rose C, Timmerman R, Ryu S, Hevezi JM, et al. American Society for Therapeutic Radiology and Oncology and American College of Radiology practice guidelines for the performance of stereotactic body radiation therapy. Int $\mathrm{J}$ Radiat Oncol Biol Phys. 2004; 60: 1026-1032. PMid:15519771 http://dx.doi.org/10.1016/j.ijrobp.2004.07.701 
[7] Fakiris AJ, McGarry RC, Yiannoutsos CT, Papiez L, Williams M, and Henderson MA, et al. Stereotactic body radiation therapy for early-stage non-small-cell lung carcinoma: four-year results of a prospective phase II study. Int J Radiat Oncol Biol Phys. 2009; 75: 677-682. PMid:19251380 http://dx.doi.org/10.1016/j.ijrobp.2008.11.042

[8] Nagata Y, Takayama K, Matsuo Y, Norihisa Y, Mizowaki T, Sakamoto T, et al. Clinical outcomes of a phase I/II study of 48 Gy of stereotactic body radiotherapy in 4 fractions for primary lung cancer using a stereotactic body frame. Int J Radiat Oncol Biol Phys. 2005; 63: 1427-1431. PMid:16169670 http://dx.doi.org/10.1016/j.ijrobp.2005.05.034

[9] Baumann P, Nyman J, Lax I, Friesland S, Hoyer M, Ericsson SR, et al. Factors important for efficacy of stereotactic body radiotherapy of medically inoperable stage I lung cancer. A retrospective analysis of patients treated in the Nordic countries. Acta Oncol. 2006; 45: 787-795. PMid:16982541 http://dx.doi.org/10.1080/02841860600904862

[10] Fritz P, Kraus HJ, Muhlnickel W, Hammer U, Dolken W, Engel-Riedel W, et al. Stereotactic, single-dose irradiation of stage I non-small cell lung cancer and lung metastases. Radiat Oncol. 2006; 1: 30. PMid:16919172 http://dx.doi.org/10.1186/1748-717X-1-30

[11] Onimaru R, Shirato H, Shimizu S, Kitamura K, Xu B, Fukumoto S, et al. Tolerance of organs at risk in small-volume, hypofractionated, image-guided radiotherapy for primary and metastatic lung cancer. Int J Radiat Oncol Biol Phys. 2003; 56 : 126-135. http://dx.doi.org/10.1016/S0360-3016(03)00095-6

[12] Onishi H, Shirato H, Nagata Y, Hiraoka M, Fujino M, Gomi K, et al. Hypofractionated stereotactic radiotherapy (HypoFXSRT) for stage I non-small cell lung cancer: updated results of 257 patients in a Japanese multi-institutional study. J Thorac Oncol. 2007; 2: S94-S100. PMid:17603311 http://dx.doi.org/10.1097/JTO.0b013e318074de34

[13] Timmerman R, McGarry R, Yiannoutsos C, Papiez L, Tudor K, DeLuca J, et al. Excessive toxicity when treating central tumors in a Phase II study of stereotactic body radiation therapy for medically inoperable early-stage lung cancer. J Clin Oncol. 2006; 24: 4833-4839. PMid:17050868 http://dx.doi.org/10.1200/JCO.2006.07.5937

[14] Wulf J, Haedinger U, Oppitz U, Thiele W, Mueller G, Flentje M. Stereotactic radiotherapy for primary lung cancer and pulmonary metastases: a noninvasive treatment approach in medically inoperable patients. Int J Radiat Oncol Biol Phys. 2004; 60: 186-196. PMid:15337555 http://dx.doi.org/10.1016/j.ijrobp.2004.02.060

[15] Xia T, Li H, Sun Q, Wang Y, Fan N, Yu Y, et al. Promising clinical outcome of stereotactic body radiation therapy for patients with inoperable stage I/II non-small-cell lung cancer. Int J Radiat Oncol Biol Phys. 2006; 66: 117-125. PMid:16765528 http://dx.doi.org/10.1016/j.ijrobp.2006.04.013

[16] Haffty BG, Goldberg NB, Gerstley J, Fischer DB, Peschel RE. Results of radical radiation therapy in clinical stage I, technically inoperable non-small-cell lung cancer. Int J Radiat Oncol Biol Phys. 1988; 15: 69-73. http://dx.doi.org/10.1016/0360-3016(88)90348-3

[17] Kaskowitz L, Graham MV, Emami B, Halverson KJ, Rush C. Radiation therapy alone for stage I non-small-cell lung cancer. Int J Radiat Oncol Biol Phys. 1993; 27: 517-523. http://dx.doi.org/10.1016/0360-3016(93)90374-5

[18] Krol AD, Aussems P, Noordijk EM, Hermans J, Leer JW. Local irradiation alone for peripheral stage I lung cancer: could we omit the elective regional nodal irradiation? Int J Radiat Oncol Biol Phys. 1996; 34: 297-302. http://dx.doi.org/10.1016/0360-3016(95)00227-8

[19] Uematsu M, Shioda A, Suda A, Fukui T, Ozeki Y, Hama Y, et al. Computed tomography-guided frameless stereotactic radiotherapy for stage I non-small-cell lung cancer: a 5 year experience. Int J Radiat Oncol Biol Phys. 2001; 51: 666-670. http://dx.doi.org/10.1016/S0360-3016(01)01703-5

[20] Timmerman R, Paulus R, Galvin J, Michalski J, Straube W, Bradley J, et al. Stereotactic body radiation therapy for inoperable early stage lung cancer. JAMA. 2010; 303: 1070-1076. PMid:20233825 http://dx.doi.org/10.1001/jama.2010.261

[21] Hoyer M, Roed H, Hansen AT, Ohlhuis L, Peterson J, Nellemann H, et al. Prospective study of stereotactic radiotherapy of limited-stage non-small-cell lung cancer. Int J Radiat Oncol Biol Phys. 2006; 66: S128-S134. http://dx.doi.org/10.1016/j.ijrobp.2006.01.012

[22] Dunlap NE, Cai J, Biedermann GB, Yang W, Benedict SW, Sheng K, et al. Chest wall volume receiving $>30$ Gy predicts risk of severe pain and/or rib fracture after lung stereotactic body radiotherapy. Int J Radiat Oncol Biol Phys. 2010; 76: $796-801$. PMid:19427740 http://dx.doi.org/10.1016/j.ijrobp.2009.02.027

[23] Pettersson N, Nyman J, Johansson KA. Radiation-induced rib fractures after hypofractionated stereotactic body radiation therapy of non-small cell lung cancer: A dose- and volume-response analysis. Radiother Oncol. 2009; 91: 360-368. PMid:19410314 http://dx.doi.org/10.1016/j.radonc.2009.03.022

[24] Voroney JP, Hope A, Dahele MR, Purdie TG, Franks KN, Pearson S, et al. Chest wall pain and rib fracture after stereotactic radiotherapy for peripheral non-small cell lung cancer. J Thorac Oncol. 2009; 4: 1035-1037. PMid:19633478 http://dx.doi.org/10.1097/JTO.0b013e3181ae2962 
[25] Trovo M, Linda A, El Naqa I, Javidan-Nejad C, Bradley J. Early and late lung radiographic injury following stereotactic body radiation therapy (SBRT). Lung Cancer. 2010; 69: 77-85. PMid:19910075 http://dx.doi.org/10.1016/j.lungcan.2009.09.006

[26] Hoppe BS, Laser B, Kowalski AV, Fontenla SC, Pena-Greenberg E, Yorke ED. Acute skin toxicity following stereotactic body radiation therapy for stage I non-small-cell lung cancer: who's at risk? Int J Radiat Oncol Biol Phys. 2008; 72: $1283-1286$. PMid:19028267 http://dx.doi.org/10.1016/j.ijrobp.2008.08.036

[27] Habel LA, Ray T, Silverberg MJ. The epidemiology of Herpes Zoster in Patients with Newly Diagnosed Cancer [abstract]. Cancer Epidemiol Biomarkers. 2012.

[28] Dunst J, Steil B, Furch S, Fach A, Bormann G, Marsch W. Herpes zoster in breast cancer patients after radiotherapy. Strahlenther Onkol. 2000; 176: 513-516. PMid:11143525 http://dx.doi.org/10.1007/PL00002318

[29] Timmerman RD, Kavanagh BD. Stereotactic body radiation therapy. Curr Probl Cancer. 2005; 29: 120-157. PMid:16059851 http://dx.doi.org/10.1016/j.currproblcancer.2005.05.001

[30] Halford WP, Gebhardt BM and Carr DJ. Mechanism of herpes simplex virus type 1 reactivation. J Virol. 1996; 70: 5051-5060. PMid:8764012

[31] Hurwitz MD, Kaur P, Nagaraja GM, Bausero MA, Manola J and Asea A Radiation therapy induces circulating serum Hsp72 in patients with prostate cancer Radiother Oncol. 2010; 95: 350-358. PMid:20430459

http://dx.doi.org/10.1016/j.radonc.2010.03.024 